\title{
SUSTAINABLE USE OF MARGINAL LANDS TO IMPROVE FOOD SECURITY IN THE UNITED ARAB EMIRATES
}

\section{Asad Sarwar Qureshi}

Senior Scientist - Irrigation and Water Management,

International Center for Biosaline Agriculture (ICBA), P.O. Box 14660, Dubai, UAE.

Received - June 08, 2017; Revision - June 28, 2017; Accepted - July 05, 2017

Available Online - August 31, 2017

DOI: http://dx.doi.org/10.18006/2017.5(Spl-1-SAFSAW).S41.S49

\section{KEYWORDS \\ Halophytes \\ marginal environment \\ salt-affected lands \\ salinity}

United Arab Emirates

\section{* Corresponding author}

E-mail: a.qureshi@biosaline.org.ae (Asad Sarwar Qureshi)

Peer review under responsibility of Journal of Experimental Biology and Agricultural Sciences.

Production and Hosting by Horizon Publisher India [HPI] (http://www.horizonpublisherindia.in/).

All rights reserved.

\begin{abstract}
In the United Arab Emirates (UAE), about 34 percent of the area is affected with different levels of salinity, where growth of normal plants is almost impossible. The extremely low rainfall and occurrence of brackish groundwater for irrigation further complicates the crop production issues. In the hyper-arid environment of UAE, integrating trees and shrubs with other farm enterprises could be a useful strategy to increase system's productivity. Field studies conducted on UAE soils have shown that Acacia ampliceps can fix nitrogen under different salinity levels ranging from 10 to $30 \mathrm{dSm}^{-1}$, thus supporting the nutrient requirements for the two grasses i.e. Sporobolus arabicus and Paspalum vaginatum. These grasses produced up to 28 tons ha $^{-1} \mathrm{yr}^{-1}$ of dry matter. When harvested at $2 \mathrm{~m}$ from the ground surface, these trees additionally provided $\sim 10$ tons $\mathrm{ha}^{-1} \mathrm{yr}^{-1}$ of foliage. The nitrogen fixation by the Acacia trees increases soil nitrogen to support forages. In the (Sabkha) coastal areas, growing halophytic plants such as Atriplex species can be beneficial due to low annual maintenance costs and their ability to survive high salt contents in the soil. Once the soil improves, non-halophytic trees, shrubs and grasses can also be planted. Until now 76 halophyte species have been identified for the UAE, which include 14 seawater tolerant halophytes, 29 halophytes, 31 semi-halophytes, and two parasitic plants belonging to Chenopodaceae and Zygophyllaceae family. The transformation of these saline lands into productive lands through large-scale adoption of halophytes and salt-tolerant plant species can have a significant impact on the livelihood and food security of rural pastoral communities of the dry regions.
\end{abstract}

All the article published by Journal of Experimental Biology and Agricultural Sciences is licensed under a Creative Commons Attribution-NonCommercial 4.0 International License Based on a work at www.jebas.org.

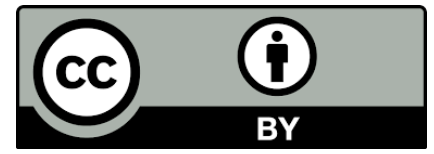




\section{Introduction}

Salinization of land and water resources is now widely known as a rising global problem to sustain agricultural production in arid and semi-arid regions of the world (Ventura \& Sagi 2013; Hasanuzzaman et al., 2014). Currently, 1,030 million hectares (Mha) are affected by twin problems of salinity and sodicity, of which 412 Mha are affected by salinity and 618 Mha by sodicity (Wicke et al., 2011).These estimates do not present the area where both salinity and sodicity problems occur together. The salinity problems are the result of both natural (primary salinity) and human-induced (secondary salinity) processes. Secondary salinity affects 76 Mha, which are distributed in different continents highest being in Asia (53 Mha) (Dregne et al.,1991; Wicke et al., 2011). Out of the total $76 \mathrm{Mha}, 43$ Mha are in irrigated lands of (semi-) arid regions of the world whereas the rest 33 Mha are in non-irrigated lands. Secondary salinization has resulted due to the poor water management practices in irrigated lands and clearing of deep-rooted native vegetation in rainfed areas (Marcar et al., 1999).

The soil salinization is also wide spread in the Middle East and North Africa (MENA) region, where 11 percent of the area is affected by soil salinity (Wicke et al., 2011). Salt-affected soils vary in extent from 15 percent in Algeria to over 50 percent in Iraq. In Kuwait, more than 50 percent of the lands and about 54 percent of the cultivated area in Saudi Arabia suffers from salinity (Abdelfattah \& Shahid, 2007). In Egypt, 93 percent of the cultivated lands whereas in Iran about 25 Mha are affected by salinity and water logging (Qadir et al., 2008). In the UAE, about 34 percent area is affected by salinity (EAD, 2009). The areas along the coastal sabkha (salt marshes or lagoonal deposits) are highly salinized $\left(28 \mathrm{dSm}^{-1}\right)$ whereas in the coastal region of the Abu Dhabi Emirate, salinity is more than $200 \mathrm{dSm}^{-1}$ (Abdelfattah $\&$ Shahid, 2007). In these areas, growth of normal plants is almost impossible.

Natural desert ecosystems (such as UAE) are vulnerable to climate change and desertification. Increasing occurrences of extreme climatic events (such as droughts) and soil salinization has increased the incursion of non-native annual plants, which has resulted in reduced productivity of hyper-arid ecosystems (Toderich et al., 2013; Hussain et al., 2016).To improve livelihood of rural pastoral communities, these salt-affected areas need to be transformed into productive lands. Afforestation has the potential to re-vegetate saline lands to provide economic benefits to pastoral communities from marginal lands and lowering high water table conditions through bio-drainage (Heuperman et al., 2002; Marcar \& Craw-Ford 2004; Khamzina et al., 2008). However, for long-term sustainability, afforestation needs to be preceded after complete evaluation of suitable tree species because salt-tolerant plant species respond differently to prevailing saline land and water conditions (Toderich et al., 2009).
Over the last three decades, many plant species have shown the potential to survive in the harsh saline environment of UAE. Recently, trend of growing arable crops in association with trees (agroforestry) has become popular. Because most trees are drought tolerant, they are capable to provide fuel, fodder, fruit and other products even if the crops fail. This paper reviews the information available on species of trees, shrubs, grasses and halophytes suitable for the saline soil and water conditions of the UAE. The prospects of agroforestry to improve productivity of desert ecosystems in the UAE is also discussed.

\section{Marginal environments}

Marginal environments are defined as the areas where salinization of land and water resources restrict potential crop production. Marginal lands have poor permeability, high salt contents, shallow water table conditions and other associated problems which restrict agricultural production. These lands are distributed in the entire world, regardless of climatic conditions and geographical occurrence. However, the criteria of marginality may vary based on their specific use (Anderson, 2012). Most conservative estimates suggest that about 10 percent of the total arable land in the world is affected by salinity and sodicity extending into more than 100 countries and almost all continents (Wicke et al., 2011). In the Middle East, 11 percent area is affected by soil salinity and agriculture is constrained due to shortage of good quality soil and water (Hussein, 2001). Therefore, percentage of population engaged in agriculture is very low i.e. ranging from less than one percent in Qatar to 29 percent in Oman. Therefore, the contribution of agriculture in the total GDP of these countries is also less than one percent.

In the Middle East, land degradation is the result of brackish groundwater use for irrigation, insufficient leaching of salts and upward movement of saline groundwater. Rising sea levels along with the over-exploitation of fresh water resources also cause sea water intrusion in coastal zones. Increasing pressure on land resources to grow more food, rising living standards, fast depletion of fresh water resources and poor management practices have further aggravated the problem. Therefore, there is every motivation to designate more resources to reclaim degraded soils to ensure future food security for the fast-growing population of different regions especially in the Middle East.

Sustainable agricultural production from marginal lands can be attained by adopting integrated natural resource management approach. This approach includes all aspects of soil, water, plants and climate to find long-term sustainable solutions for the marginal lands and waters. The "biosaline agriculture" is one of the promising approaches to deal with these situations. This approach is based on adaptable technology packages composed of salt-tolerant fodders and halophytes integrated with livestock and appropriate management systems (on-farm irrigation, soil fertility, etc.). The Biosaline approach helps in reclaiming saline lands 
through the cultivation of salt-tolerant cereal and forage crops and plantation of trees. Plantation of salt-tolerant trees in combination with the salt tolerant plants is an economically viable proposition for saline areas. Salt-tolerant tress can be used as timber, firewood, fodder (e.g. Actlcia nilotica, Acacia saligna), soil and water erosion control, wildlife corridors and aesthetics. The trees also act as windscreens, add organic matter and nitrogen and improve soil structure by breaking hard pans. The proper selection of plant species is the key for productive agroforestry because different crops and trees show varying reactions to salinity stress.

To maximize advantages, suitable selection of shrubs and grasses considering prevailing edaphic and climatic conditions of the area is of paramount importance. This is particularly important for good to moderate environments where shrubs could be used for forage and fodder purposes. The shrubs and grasses have widely been used for amelioration and reclamation of salt-affected and waterlogged soils (Sandhu \& Qureshi, 1986; Ahmad \& Ismail, 1993; Barrett-Lennard \& Galloway, 1996; Toderich et al., 2013). The species such as Prosopis, Tamarix and Atriplex, are naturally occurring plants in coastal or inland areas where soils are saline and groundwater quality is brackish. These plants are usually referred as halophytes. Marcar et al. (1999) have provided a list of salt-tolerant tree and shrub species for marginal environments as given in Table 1 .

\section{The Case of United Arab Emirates (UAE)}

The United Arab Emirates (UAE) is in the south-eastern part of the Arabian Peninsula and borders Oman and Saudi Arabia. The total area of the country is $82,880 \mathrm{~km}^{2}$ (Figure 1). Abu Dhabi is the largest of seven Emirates and accounts for 87 percent of the total land mass of the country. The main characteristics are limited arable land, harsh climate and poor renewable water resources. The UAE is dominated by lowlying, sandy desert with extensive salt flats (sabkha) present in coastal areas. The country has an arid to hyper-arid climate with high temperatures and low rainfall. The summers (May to October) months are extremely hot with daytime temperatures frequently above $40^{\circ} \mathrm{C}$. Rainfall is generally restricted to winter months (November to March), when night time temperatures can drop to $4^{\circ} \mathrm{C}$. Precipitation generally decreases from northeast to southwest. The eastern mountainous areas receive up to $480 \mathrm{~mm}$ rainfall per year compared to only 80 $\mathrm{mm}$ in coastal areas and far less in western and southern parts of the country. Groundwater quality is awfully poor (15-30 $\mathrm{dSm}^{-1}$ ), which makes it unsuitable for irrigation purposes for normal crop production.

The extent of soil salinization in the UAE has changed over time. It is estimated that about 25 percent area is affected by salinity. The soil salinity ranges from 2 to $10 \mathrm{dSm}^{-1}$ for most of the agricultural systems (Karim \& Dakheel, 2006). However,
Table 1 Suitability of tree and shrub species under different soil salinity, sodicity and waterlogging conditions

\begin{tabular}{|c|c|c|c|}
\hline Species & $\begin{array}{c}\text { Salinity } \\
\left(\mathrm{EC}_{\mathrm{e}}=\mathrm{dSm}^{-1}\right)\end{array}$ & Sodicity & Waterlogging \\
\hline Acacia ampliceps* & Severe & Severe & No \\
\hline A. auriculiformis* & Moderate & & Yes \\
\hline A. cyclops & High & & \\
\hline A. machonochiena & Severe & Severe & \\
\hline A. nilotica Moderate & Moderate & High & \\
\hline A. salicina & High & High & \\
\hline A. saligna Moderate & Moderate & Moderate & \\
\hline A. stenophylla & Severe & Severe & Yes \\
\hline A. tortilis Moderate & Moderate & & \\
\hline Ailanthus excelsa & High & Moderate & \\
\hline Albizia lebbeck & Moderate & Moderate & \\
\hline A. procera & & Moderate & Yes \\
\hline Azadirachta indica & Moderate & & \\
\hline Butea monosperma & Moderate & High & \\
\hline Casuarina cristata & Moderate/High & Moderate & Yes \\
\hline C. cunninghamiana & Moderate/High & & Yes \\
\hline C. equisetifolia & Moderate & High & Yes \\
\hline C. glauca* & High & Moderate/High & Yes \\
\hline C. obesa* & High/Severe & High & \\
\hline Cepparis aphylla & High & & \\
\hline Conocarpus lancifolius & High & & \\
\hline Dalbergia sissoo & Moderate & Moderate & \\
\hline Eucalyptus brassiana & Moderate/High & & \\
\hline E. camaldulensis* & Moderate & High & Yes \\
\hline E. citriodora & Moderate & & \\
\hline E. grandis* & Slight/Moderate & & Yes \\
\hline E. coolabah & Moderate & High & \\
\hline E. moluccana & Moderate & & \\
\hline E. occidentalis* & High & & \\
\hline E. platypus & Moderate & Moderate & Yes \\
\hline E, raveretiana & High & & \\
\hline E, robusta & Moderate & & \\
\hline E, rudis & High & & \\
\hline E, spathulata & High & Moderate & Yes \\
\hline E. tereticornis* & Moderate & High & \\
\hline Leucaena leucocephala & High & Moderate & \\
\hline Melaleuca arcana & Moderate & & \\
\hline M. bracteata & Moderate & Moderate/High & Yes \\
\hline M. halmaturorum & Severe & Moderate & Yes \\
\hline M. lanceolata & High & & Yes \\
\hline M. leucadendra & High & & Yes \\
\hline M. quinquinervia & Moderate & Low & Yes \\
\hline Parkinsonia aculeate & Moderate & & Yes \\
\hline Pinus halepensis & Moderate & & \\
\hline Pongamia pinnata & Moderate & & \\
\hline Populus euphratica & Moderate & & \\
\hline Prosopis chilensis & & High & \\
\hline P. juliflora & Severe & High & Yes \\
\hline Sesbania formosa & Moderate & & Yes \\
\hline S. grandiflora & Moderate & & Yes \\
\hline T amarix aphy/la & Severe & & Yes \\
\hline T. articulata & Severe & & Yes \\
\hline T erminalia arjuna & High & Moderate/High & \\
\hline Zizyphus jujube & High & & Yes \\
\hline Z. spina-vulgaris & High & & Yes \\
\hline
\end{tabular}




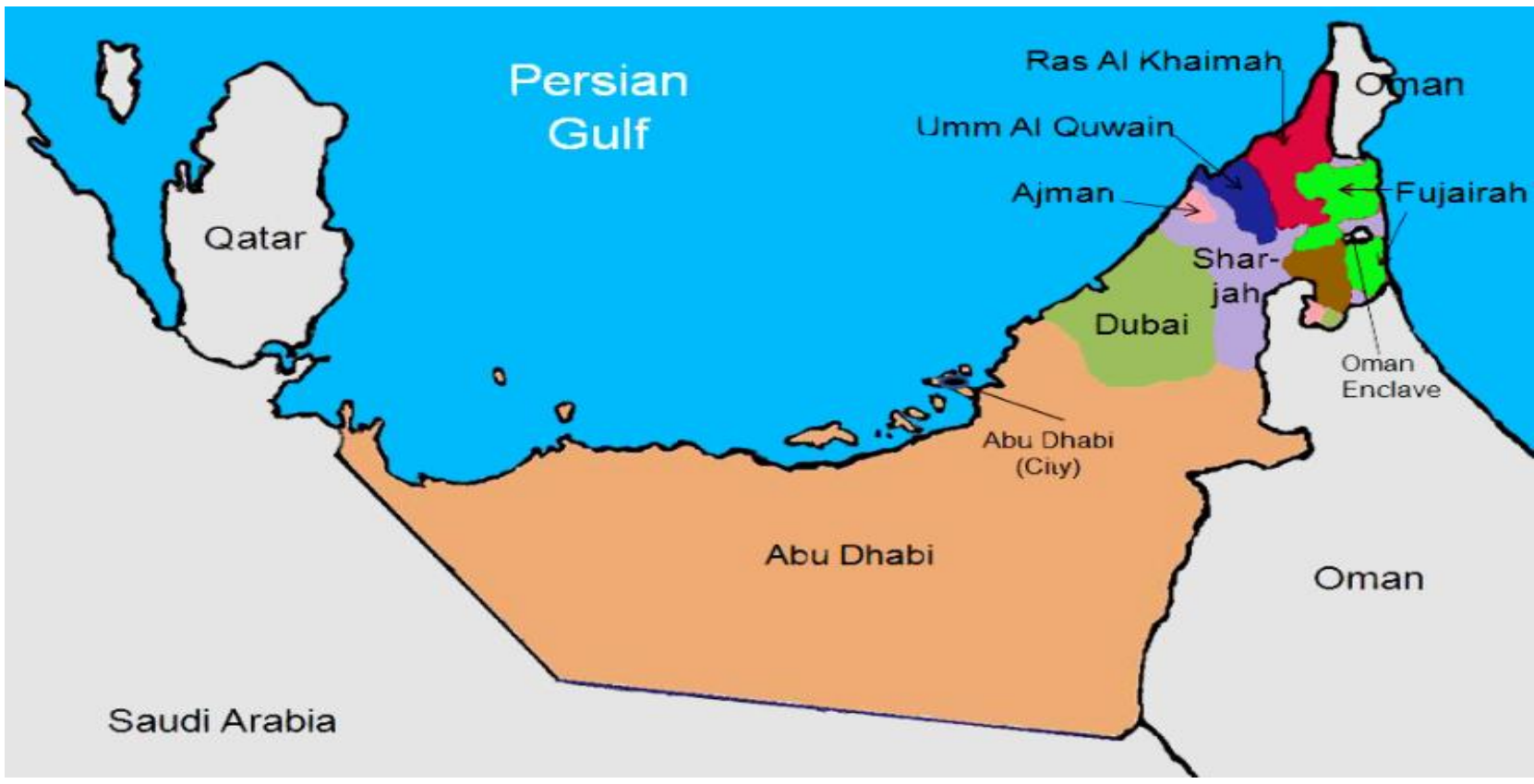

Figure1 Map of United Arab Emirates

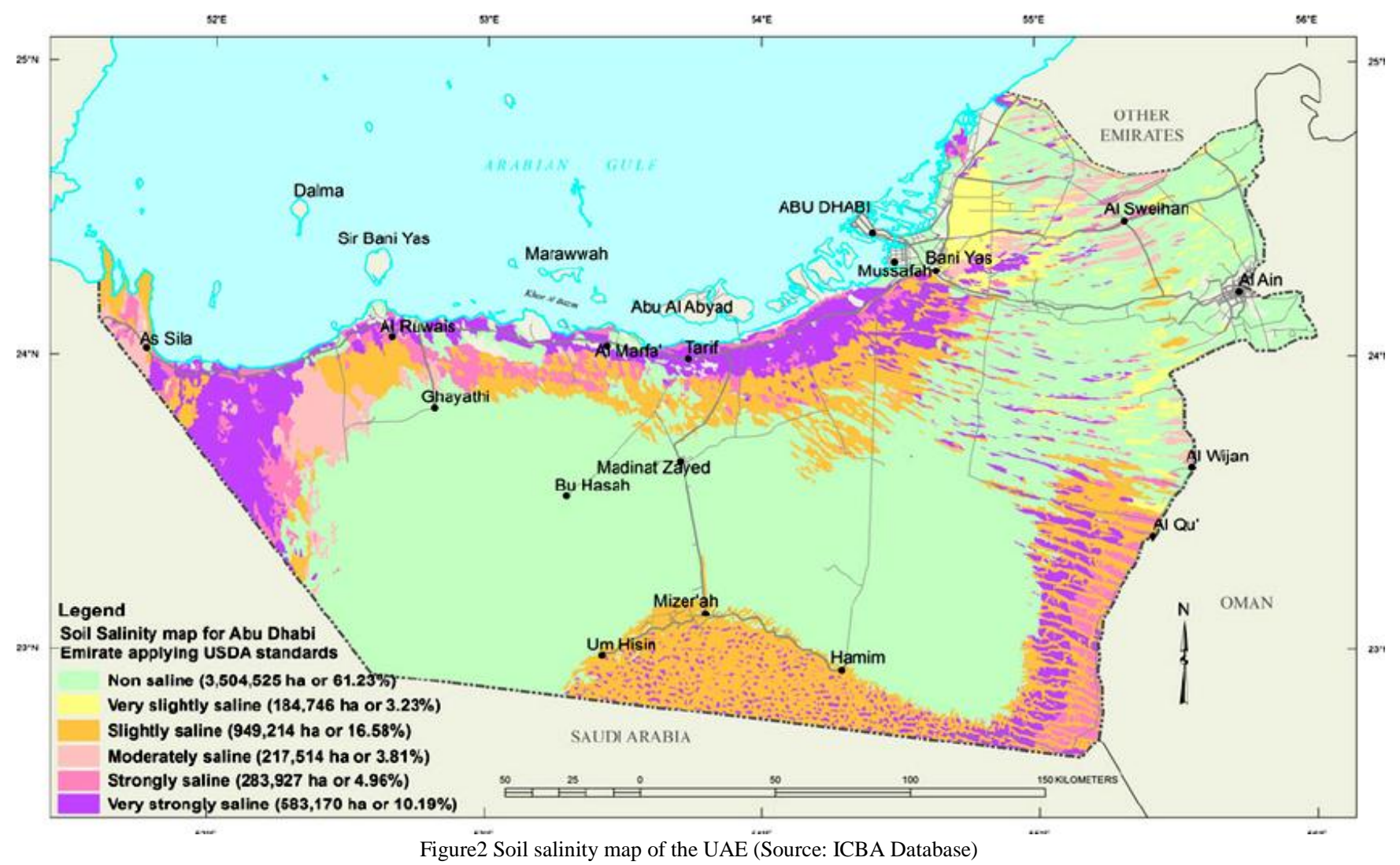

in many parts, soil salinity can go up to $20 \mathrm{dSm}^{-1}$ in forage (Rhodes grass) grown areas and $25 \mathrm{dSm}^{-1}$ in areas where native plants (Prosopis cineraria and Acacia tortilis) are grown. The use of highly saline groundwater $\left(20-25 \mathrm{dSm}^{-1}\right)$ for irrigation is the major cause of this high soil salinity. The salinity on older UAE farms is also very high, ranging from $15-20 \mathrm{dSm}^{-1}$. The differences in the soil salinity and $\mathrm{pH}$ values in extreme sabkhas of the UAE are given in Table 2. The soil salinity map of UAE is shown in Figure 2.

Journal of Experimental Biology and Agriculture Science http://www.jebas.org 
Table 2 Measurements of salinity and $\mathrm{pH}$ on UAE farms and various sabkhas

\begin{tabular}{|lcccc|}
\hline \multicolumn{1}{c}{ Location } & \multicolumn{2}{c}{ Soil salinity in farms } & \multicolumn{2}{c|}{ Soil salinity in sabkhas } \\
\hline Abu Dhabi & $7.1-9.0$ & $4.0-38.0$ & 8.0 & 73.0 \\
\hline Dubai & $7.1-9.0$ & $1.0-38.0$ & 8.6 & 231.0 \\
\hline Sharjah & $9.0-9.8$ & $0.2-10.8$ & 9.1 & 67.4 \\
\hline Ajman & $8.9-9.2$ & $1.4-3.0$ & 8.1 & 116.9 \\
\hline Umm al-Qaiwan & $8.2-8.5$ & $2.5-4.2$ & 7.7 & 15.6 \\
\hline R'as al-khaimah & $4.2-8.9$ & $0.7-17.7$ & 8.5 & 191.6 \\
\hline Al Ain & $0.5-27.0$ & $7.7-9.4$ & 8.0 & 300.0 \\
\hline Tarif & 8.0 & 82.0 & 7.2 & 213.0 \\
\hline Sabkhat Matti & 7.8 & 98.0 & 6.6 & 219.0 \\
\hline Fujairah & $8.0-9.9$ & $0.5-10.5$ & 8.4 & 74.0 \\
\hline
\end{tabular}

The UAE soils are divided into three categories for plant growth (Karim \& Dakheel, 2006).

\subsection{Farmlands salinized due to poor irrigation practices}

These lands can be reclaimed by leaching of salts using fresh water to grow conventional crops. However, in the absence of leaching facility, growing salt-affected crops may be given serious consideration

\subsection{Arid lands with brackish groundwater}

Growth of sensitive crops is restricted in these areas. However, these lands have the potential to grow selected salt-tolerant crops by applying special cultural techniques and using of brackish groundwater for irrigation.

\subsection{Coastal deserts}

In the extensive coastal area of the UAE, most farmers are reluctant to grow crops/plants because soils are extremely sandy and only sea water is available for irrigation. In these areas, growing halophytes and highly salt-tolerant plants have the potential to generate significant income for the farmers.

Salt-tolerant plants and halophytes found on seashores and estuaries can be used to meet requirements of food, fiber, fuel and medicines. Due to these benefits, their potential use in the UAE is increasing. Many salt-tolerant genotypes of food crops have also been identified, which can be grown effectively using saline groundwater to achieve economical returns. These include carrots, onions, tomatoes, date palm, pearl millet, barley, sorghum, maize and wheat.

Salt-tolerant grasses such as Chloris guayana (Rhodes grass), Panicum turgidum, Pennisetum spp., Lasiurus spp., along with many trees and shrubs are commonly used for grazing. Perennial salt bushes (Attriplex spp.) and forage herbs like Medicago spp. and Trifolium spp. are grown throughout the UAE due to their salt-tolerance. Salt-tolerant trees such as Acacia spp., P. cineraria, L. leucocephala, and $P$. juliflora are best suited for use as windbreaks and additional sources of fodder for livestock, which consume their pods, leaves and branches.

The salt-tolerant plants such as Hibiscus spp., Juncus spp., Typha spp. and Phragmites australis are suitable for fiber use. The latter is a marsh plant and commonly used for fencing, roofing, basket making and fuel wood. The Sesbania bispinosa is a well-known salt-tolerant legume and fodder crop, which is also used as a fuel and fiber. The plants such as Tamarix, Casuarina, Acacia, Prosopis, Eucalyptus, Avicennia and Rhizophora are widely used as fuelwood. Many local plants are used as medicine for treating illnesses, such as diabetes, arthritis, high blood pressure, and urinary tract disorder (Karim \& Dakheel, 2006).

\section{Prospects of agroforestry in the UAE}

Over the last 15 years, International Center for Biosaline Agriculture (ICBA) has done the pioneer work in integrating trees and shrubs with other farm enterprises to increase the system's productivity in the UAE. The focus has been on the evaluation of the feasibility of Acacia ampliceps for Central Asia to North Africa regions because this plant has the capacity to fix atmospheric nitrogen, provides forage for animals and produce bio-energy (Toderich et al., 2013). ICBA's research has demonstrated the compatibility between A. ampliceps and two salt-tolerant grasses i.e. Sporobolus arabicus and Paspalum vaginatum in response to different salinity and fertilizer treatments.

Field studies conducted on UAE soils have shown that Acacia ampliceps can fix nitrogen under different salinity levels (10-30 $\mathrm{dSm}^{-1}$ ), thus supporting the nutrient requirements for the two grasses i.e. S. arabicus and P. vaginatum (Toderich et al., 2013). Based on average values over the study period, the unfertilized plots showed a 7 to 13 percent reduction in biomass yields for $S$. arabicus but insignificant difference for $P$. vaginatum. These grasses produced up to 28 tons of dry matter $\mathrm{ha}^{-1} \mathrm{yr}^{-1}$. When harvested at $2 \mathrm{~m}$ from the ground surface, these trees additionally provided $\sim 10$ tons $\mathrm{ha}^{-1} \mathrm{yr}^{-1}$ of foliage. The nitrogen fixation by the Acacia trees increases soil nitrogen to support forages. In the (Sabkha) coastal areas, growing halophytic plants such as Atriplex species can be beneficial due to low annual maintenance costs and their ability to survive high salt contents in the soil. The nitrogen 
fixation by the Acacia trees helps in increasing the forage production.

The studies done by ICBA have shown that integrated trees and shrub systems such as alley-cropping, silvopasture, windbreaks, riparian buffer strips, and forest farming for non-timber forest products are advantageous for enhancing productivity of marginal lands (Toderich et al., 2009). In addition, these agroforestry systems can improve soil nutrient management thereby increasing the productivity of plants. The most commonly used alleycropping system is where agricultural crop is grown simultaneously with a long-term tree crop. This practice enhances income diversity, control erosion, improve nutrient utilization and increase crop production. When designing an alley-cropping system, consideration must be given to the type of tree and crops that can be grown together for optimizing economic gains. There are many tree and crop combinations that can be practiced. The four basic groups of companion crops are given below:

1. Cereal crops - Wheat, barley, corn, soybeans, potatoes, oats, peas, and beans

2. Forage/fodder crops - Orchard grass, bluegrass, ryegrass, brome, clover, alfalfa. The production of forages may be enhanced in the shade of analley- cropping practice.

3. Specialty crops - Landscape plants like blue spruce, dogwood, redbud; Christmas trees;small fruit trees; or crops like goldenseal or ginseng.

4. Biomass crops - Trees including poplars, willows, silver maple, birches (herbaceouscrops like switchgrass).

For successful agroforestry systems, the tree species should have high commercial or environmental value and the capacity to create suitable micro-environments for the companion agricultural crops. Alley-cropping practices are highly diverse therefore the knowledge of the growth characteristics of trees and the companion crops is necessary to determine suitable crop combinations and to decide whether plantation is done in single or multiple rows. Since growth rates of different species may conflict, proper designing is important to avoid dominance of certain species and their negative effects on others.

\section{Halophytes for agroforestry in the UAE}

Halophytes can tolerate high levels of salts and/or sodium in soil or in irrigation water and are suitable to protect habitats, maintain ecological stability and developing agriculture in saline soils. They can grow in marshes, estuaries, cliffs and dunes and constitute about one percent of the world's flora (Flowers \& Colmer, 2008). The facultative halophytes are also suitable for freshwater conditions, while obligate halophytes can only grow in saline lands. Halophytes are suitable for coastal and inland soils of arid and semiarid climates, where evapotranspiration is remarkably higher than the precipitation (Manousaki \& Kalogerakis, 2011). They have the capacity to tolerate salinity by adjusting their internal water relations through ionic compartmentation in cell vacuoles, accumulation of compatible organic solutes, succulence, and salt secreting glands and bladders (Shabala \& Mackay, 2011). Halophytes remove salts from soils through different processes such as salt excluding, excreting, or accumulating by their morphological, anatomical, and physiological adaptations in their organelle level and cellular level (Hasanuzzaman et al., 2014). Some studies have also shown the ability of halophytic plants to remove heavy metals from normal and salt-affected soils (Manousaki \& Kalogerakis, 2009; Nedjimi \& Daoud, 2009)

The establishment of halophytic plants such as Atriplex species can be beneficial in the coastal areas of the UAE where extensive salt flates (sabkha) exists (Figure 3). Once these soils are rehabilitated, growth of non-halophytic trees such as shrubs and grasses would be possible. Sabkha is a stiff environment for biological activity due to high salt content and lack of fresh water resources (Barth \& Böer, 2002). However, halophytes have the potential to inhabit thin layers of aeolian sand that is deposited on the sabkha surface due to local weather conditions to support dense vegetation (Gairola et al., 2015). In these areas, major problem with halophytic vegetation is their taxonomic uncertainty and misidentification of different species (Brown, 2006). For example, some members of the Chenopodiaceae display significant morphological variation, and it is often difficult to separate one specie from the other.

Many species of halophytic plants such as Suaeda maritime, Sesuvium portulacastrum, Arthrocnemum indicum, Suaeda fruticosa, Tamarix aphylla, Atriplex nummularia, A. halimus have been used to clean contaminated soils as they can absorb more salts in their tissues thereby reducing salts from the saline land (Ravindran et al. 2007; Nasir 2009). These species are also useful for reclaiming salt-affected soils. Halophytes can maintain productivity of agricultural lands up to a salinity level of $70 \mathrm{dSm}$ ${ }^{1}$, if accumulation of salts in the root zone is maintained through effective leaching (Glenn et al.,2013).The species like Cynodon dactylon, Ruppia maritima and Inula crithmoides can produce biomass through biosaline agriculture (Öztürk et al., 2014). The Salicornia europea, a high-quality edible-oil yielding plant with high economic value, can also be used to reclaim salinized soils (Muscolo et al., 2014).

Böer (2002) have recognized 76 commonly existing halophyte species for the UAE. These include 14 seawater halophytes, 29 halophytes, 31 semi-halophytes, and two parasitic plants belonging to Chenopodaceae and Zygophyllaceae family. Since halophytic plants behave differently in regulating salt content in their tissues, it is important to explore the morpho-anatomical adaptations and physiological significance of different halophyte species. The Environmental Agency of Abu Dhabi has found that many of the halophytes can grow in hyper-saline Sabkha (salt marshes), where salinity reaches several folds greater than the sea 


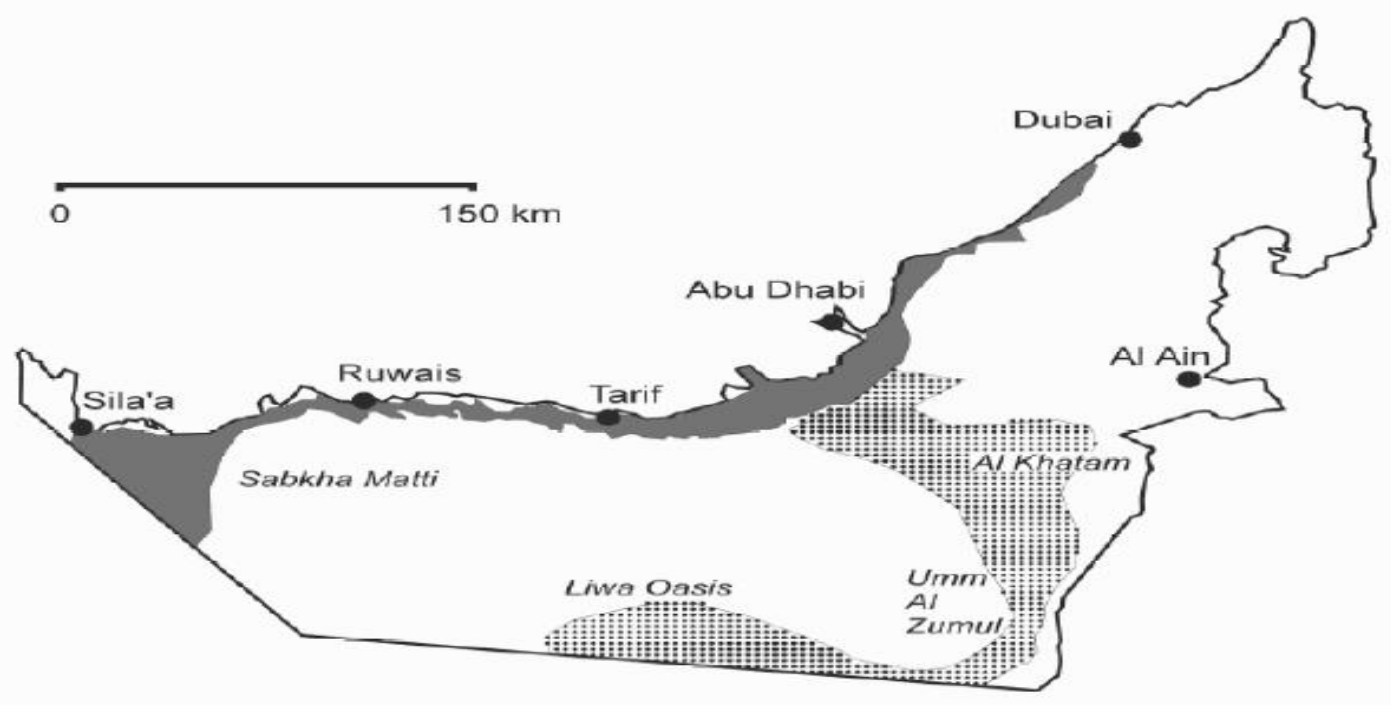

Figure3 Map of UAE showing the extent of coastal Sabkha (grey shaded area), and Sabkha Matti, as well as areas with inland Sabkhat (dotted area)

water salinity (EAD, 2012). However, they propose that more research is needed to understand structure and function of salt glands, nature of secreted material, mechanism(s) of ion secretion and the way halophytes handle the salts. This information is needed to select best halophytic species for bio-reclamation of salt-affected soils in arid and semi-arid regions of the Arabian Peninsula (Shabala, 2013). The halophytes commonly used in the coastal areas of Abu Dhabi are given Table 3.

Table 3 Plant species along the Abu Dhabi coastline and the ecosystems in which they occurs

\begin{tabular}{|c|c|c|c|}
\hline Species & Ecosystem & Species & Ecosystem \\
\hline Suaeda v. Arthrocnemum & SS & Phoenix dactylifera & SS \\
\hline Prosopis cineraria & SS & Pluchea dioscoryides & BW \\
\hline macrostachyum & SM & Sesuvium verrucosum & BW \\
\hline Salsola drummondii & SS & Aeluropus lagopoides & $\mathrm{BW}$ \\
\hline Halopeplis perfoliata & SS & Arundo donax & BW \\
\hline Avicennia marina $\mathrm{M}$ & SM & cf. Cymbopogon sp. & SS \\
\hline Halocnemum Strobilaceum & $S M$ & Dipterygium glaucum & SS \\
\hline strobilaceum & SM & Helianthemum lippii & $\mathrm{H}$ \\
\hline Zygophyllum qatarense & SS & Lotus garcinii & $\mathrm{H}$ \\
\hline Anabasis setifera & SS & cf. O. compressa & $B W$ \\
\hline Biennertia cycloptera & SS & Taverniera spartaea & $\mathrm{H}$ \\
\hline Salsola imbricata & SS & Calligonum comosum & $\mathrm{H}$ \\
\hline Zygophyllum mandavillei & SS & Euphorbia serpens & BW \\
\hline Cyperus arenarius & SS & Heliotripium dyginum & SS \\
\hline Heliotropium bacciferum & SS & Lasiurus scindicus & $\mathrm{H}$ \\
\hline Cornulaca monacantha & SS & Leptadenia pyrotechnica & SS \\
\hline Limonium axllare & SS & Limeum arabicum & SS \\
\hline Prosopis juliflora & SS & Pennisetum divisum & SS \\
\hline Tamarix sp. & BW & Phyla nodiffora & BW \\
\hline Cyperus conglomeratus & SS & Sesuvium portulacastrum & $\mathrm{BW}$ \\
\hline Salsola c. Cornulaca & $\mathrm{H}$ & Sporobolus iocladus & SS \\
\hline Salvadora persica & $\mathrm{BW}$ & Haloxylon salicornicum & $\mathrm{H}$ \\
\hline cf. leucocantha & SS & Seidlitzia rosmarinus & SS \\
\hline Halopyrum mucronatum & SS & Shpaerocoma aucheri & SS \\
\hline Panicum turgidum & SS & Ipomea pes-caprae & BW \\
\hline Phragmites australis & BW & Suaeda aegyptiaca & SS \\
\hline Atriplex leucoclada & SS & Zygophyllum simplex & SS \\
\hline Stipagrostis sp. & $\mathrm{H}$ & Chloris sp. & BW \\
\hline Sporobolus spicatus & $\mathrm{BW}$ & Farsetia cf. aegyptiaca & $\mathrm{H}$ \\
\hline Dactyloctenium scindicum & SS & & \\
\hline
\end{tabular}

Here H = (Rocky) Headlands; SS = Sand Sheets; M = Mangrove; SM = SaltMarsh; BW = Brackish Water (Source: Böers \& Saenger, 2006) Journal of Experimental Biology and Agriculture Science http://www.jebas.org 
For the Abu Dhabi Gulf coast; 59 plant species (without irrigation) have been identified. These include one species for mangroves, three salt marsh species and 55 species for areas other than mangroves or salt marsh. The sand sheet vegetation is referred to vegetation of sandy beaches or "storm berms" whereas others are marked as vegetation of brackish ground, or rocky headlands. The coastal vegetation usually forms a narrow band separated from true terrestrial vegetation by a wider band of coastal sabkhas.

\section{Conclusions and recommendations}

The world's most productive lands have already been utilized and the need to use marginal lands of lower quality is increasing to ensure food security and environmental sustainability. Over the last three decades, considerable work has been done in identifying crops, trees, shrubs and grasses that can potentially grow under marginal environments of the UAE. The salt-tolerant species of trees, shrubs and grasses have the potential of lowering the groundwater levels through either control of accessions or pumping groundwater. The extracted groundwater can be used to irrigate salt-tolerant trees, shrubs and grasses as they can tolerate Ecup to $10 \mathrm{dSm}^{-1}$ without compromising on transpiration rates. In the UAE, tree production systems can be of great value because of the presence of sandy soils and saline groundwater. However, the success of the sea water plantations will depend on the effectiveness of selected plant species grown for the management of salt concentrations in the root-zone and the concentration of sodium carbonate in the irrigation water. Since leaching fractions for the sandy soils are high, areas with deeper water tables will be most suited for these plantations. Integration of fodder halophytes into the agro-silvi-pastoral system can offer cost-effective rehabilitation of degraded rangelands and farm lands.

Promoting sustainable use of marginal land and water resources for food-feed crops and forage legumes will improve food security, reduce poverty, resilience against climate change, and enhance ecosystem health in crop-livestock systems. The adoption of native and introduced halophytes and salt-tolerant plant resources can have a significant impact on salinity control and remediation, which can lead to the economic development of saltaffected dry regions. The agroforestry concept can help in solving on-farm drainage problems and create favorable environmental conditions for the desert and semi-desert areas of the region.

\section{References}

Abdelfattah MA, Shahid SA (2007) A comparative characterization and classification of soils in Abu Dhabi coastal area in relation to arid and semiarid conditions using USDA and FAO soil classification systems. Arid Land Research and Management 21:245-271.
Ahmad R, Ismail S (1993) Studies on selection of salt-tolerant plants for food, fodder and fuel from world flora. In: Leith H, AIMasoum A (Eds.), Towards the rational use of high salinity tolerant plants. Kluwer Academic Publishers 2.295-304.

Anderson T (2012) Agrofuels and the myth of the marginal lands. The Gaia Foundation, Pp. 8.

Barrett-Lennard EG, Galloway R (1996) Saltbush for water table reduction and land rehabilitation. Australian Journal of Soil and Water Conservation 9.21-24.

Barth HJ, Böer B (Eds.) (2002) Sabkha Ecosystems. Volume 1. The Arabian Peninsula and Adjacent Countries. Kluwer, Dordrecht, Pp. 354.

Böer B (2002) The coastal and sabkha flora of the United Arab Emirates. In: Barth HJ, Böer, B (Eds.), Sabkha Ecosystems. Volume 1. The Arabian Peninsula and Adjacent Countries. Kluwer, Dordrecht, Pp. 303-309.

Böer B, Saenger P (2006) The biography of the coastal vegetation of the Abu Dhabi Gulf Coast. In: Khan MA, Böer B, Öztürk M, Al Abdessalaam TZ, Clüsener-Godt M, Gul B. (Eds.) Sabkha Ecosystems. Volume II: West and Central Asia. Springer, Netherlands. p 31-36.

Brown G (2006) The sabkha vegetation of the United Arab Emirates. Sabkha Ecosystems 42: 37-51.

Dregne H, Kassas M, Razanov B (1991) A new assessment of the world status of desertification. Desertification Control Bulletin (United Nations Environment Programme). 20. 6-18.

EAD (2009) Soil survey of Abu Dhabi Emirate. Environment Agency Abu Dhabi, United Arab Emirates, Volumes 5.

EAD (2012) Soil Survey of the Northern Emirates. A set of 3 volumes and maps. Environment Agency-Abu Dhabi, Abu Dhabi, UAE.

Flowers TJ, Colmer TD (2008) Salinity tolerance in halophytes. New Phytologist 179:945-963.

Gairola S, Bhatt A, El-Keblawy A (2015) A perspective on potential use of salt-affected lands. Wulfenia Journal 22 : 88-97.

Glenn EP, Andaya T, Chaturvedib R, Martinez-Garciaa R, Pearlsteina S, Soliza D, Felgera RS (2013) Three halophytes for saline-water agriculture: An oilseed, a forage and a grain crop. Environmental and Experimental Botany 92: 110-121.

Hasanuzzaman M, Nahar K, Alam MM, Bhowmik PC, Hossain MA, Rahman MM, Prasad M NV, Ozturk M, Fujita M (2014) 
Potential use of halophytes to remediate saline soils. - BioMed Research International. doi:10.1155/2014/589341.

Heuperman AF, Kapoor AS, Denecke HW (2002) Biodrainage principles, experiences and applications. Knowledge synthesis report no. 6, International Programme for Technology and Research in Irrigation and Drainage (IPTRID). FAO, Rome, p 79

Hussain MI, Lyra DA, Farooq M,Nikoloudakis N, Ahmad N (2016) Salt and drought stresses in safflower : A Review. Agronomy for Sustainable Development 36: 4. doi:10.1007/s13593-015-0344-8.

Hussein H (2001) Development of environmental GIS database and its application to desertification study in Middle-East. $\mathrm{PhD}$ thesis submitted to the Graduate School of Science and Technology, Chiba University, Japan.

Karim FM, Dakheel AG (2006) Salt-tolerant plants of the United Arab Emirates. International Center for Biosaline Agriculture, Dubai, UAE. 184 pp.

Khamzina A, Lamers JPA, Vlek PLG (2008) Tree establishment under deficit irrigation on degraded agricultural land in the lower Amu Darya River region, Aral Sea basin. Forest Ecology and Management 255:168-178.

Manousaki E, Kalogerakis N (2009) Phytoextraction of Pb and Cd by the Mediterranean saltbush (Atriplex halimus L.): metal uptake in relation to salinity. Environmental Science and Pollution Research 16:844-854.

Manousaki E, Kalogerakis N (2011). Halophytes - an emerging trend in phytoremediation. International Journal of Phytoremediation 13: 959-969.

Marcar NE, Ismail S, Hossain AKMA, Ahmad R (1999) Trees, shrubs and grasses for salt lands: an annotated bibliography. ACIAR Monograph No. 56, Pp. 316.

Marcar NE, Craw-Ford DF (2004) Trees for saline landscapes. Rural Industries Research and Development Corporation (RIRDC), Canberra, Pp 245.

Muscolo A, Panuccio MR, Piernik A (2014) Ecology, Distribution and Ecophysiology of Salicornia Europaea L. In: Khan MA, Böer B, Öztürk M, Al Abdessalaam TZ, Clüsener-Godt M, Gul B (Eds.) Sabkha Ecosystems. Volume IV: Cash Crop Halophyte and Biodiversity Conservation. Springer Publication, Netherlands.

Nasir FA (2009) Bioreclamation of a Saline Sodic Soil in a Semiarid Region/Jordan. American-Eurasian Journal of Agricultural and Environmental Science 5: 701-706.

Nedjimi B, Daoud Y (2009) Cadmium accumulation in Atriplex halimus subsp. schweinfurthii and its influence on growth, proline, root hydraulic conductivity and nutrient uptake. Flora 204: 316-324.

Öztürk M, Altay V, Gucel S, Guvensen A (2014). Halophytes in the East Mediterranean-Their Medicinal and Other Economical Values. In: Khan MA, Böer B, Öztürk M, Al Abdessalaam TZ, Clüsener-Godt M, Gul B (Eds.) Sabkha Ecosystems. Volume IV: Cash Crop Halophyte and Biodiversity Conservation. Springer Publication, Netherlands, Pp. 247-272.

Qadir M, Tubeileh A, Akhtar J, Larbi A, Minhas PS, Khan MA (2008) Productivity enhancement of salt-affected environments through crop diversification. Land Degradation Development 19:429-453.

Ravindran KC, Venkatesan K, Balakrishnan V, Chellappan KP, Balasubramanian $\mathrm{T}$ (2007) Restoration of saline land by halophytes for Indian soils. Soil Biology and Biochemistry 39: 2661-2664.

Sandhu GR, Qureshi RH (1986) Salt-affected soils of Pakistan and their utilization. Reclamation and Revegetation Research 5:105-113

Shabala S (2013) Learning from halophytes: physiological basis and strategies to improve abiotic stress tolerance in crops. Annals of Botany 112:1209- 1221.

Shabala S, Mackay A (2011) Ion transport in halophytes. Advances in Botanical Research 57: 151-199.

Toderich KN, Shuyskaya EV, Ismail S, Gismatullina L, Radjabov T, Bekhchanov BB, Aralova D (2009) Phytogenic resources of halophytes of Central Asia and their role for rehabilitation of sandy desert degraded rangelands. Land Degradation Development 20: 386-396.

Toderich KN, Shuyskaya EV, Taha FK, Matsuo N, Ismail S, Aralova DB, Radjabov TB (2013) Integrating Agroforestry and Pastures for Soil Salinity Management in Dryland Ecosystems in Aral Sea Basin. In: Shahid SA, Abdelfattah MA, Taha FK (Eds.), Developments in Soil Salinity Assessment and Reclamation: Innovative Thinking and Use of Marginal Soil and Water Resources in Irrigated Agriculture, Springer Science+Business Media Dordrecht 2013.

Ventura Y, Sagi M (2013) Halophyte crop cultivation: The case for Salicornia and sarcocornia. Environmental and Experimental Botany 92:144-153.

Wicke B, Smeets E, Dornburg V, Vashev B, Gaiser T, Turkenburg W, Faaij A (2011) The global technical and economic potential of bioenergy from salt-affected soils. Energy Environmental Science 8: 2669e2681. 